\title{
Synthesis and characterization of phosphorus-containing dendrimers bearing rhodamine derivatives as terminal groups
}

\author{
Yiqian Wei, Régis Laurent, Jean-Pierre Majoral,* and Anne-Marie Caminade* \\ CNRS; LCC (Laboratoire de Chimie de Coordination); 205 route de Narbonne, \\ F-31077 Toulouse, France \\ and Université de Toulouse; UPS, INPT; LCC; F-31077 Toulouse, France \\ E-mail: majoral@lcc-toulouse.fr, caminade@lcc-toulouse.fr
}

\begin{abstract}
The synthesis of two new derivatives of Rhodamine B functionalized by phenols is reported. For one rhodamine derivative, the equilibrium between the open form and the ring-closed (spirolactam) form is completely shifted toward the latter, whereas the constitution of the other rhodamine derivative precludes ring closure. The spirolactam derivative was grafted as terminal group to a first generation phosphorus-containing dendrimer. Attempts to open the spirolactam form by adding $\mathrm{HCl}$ failed and resulted only in protonation of the $\mathrm{NEt}_{2}$ substituent of rhodamine.
\end{abstract}

Keywords: Dendrimers; rhodamine, chromophore, phosphorus, spirolactam

\section{Introduction}

Rhodamine derivatives pertain to one of the most largely used family of chromophores, owing to their photostability, high fluorescence intensity, and low cost compared to many other types of fluorophores. Beside the application as textile dyes, rhodamines are often used as sensitive labels or tracers for biological experiments, and as chemo-sensors for sensing ions. ${ }^{1}$ This property is due to a $\mathrm{pH}$-driven ring-opening / ring-closure (Scheme 1); the open form 1A is colored and highly fluorescent, whereas the ring-closed form 1B is colorless and non-fluorescent. ${ }^{2}$

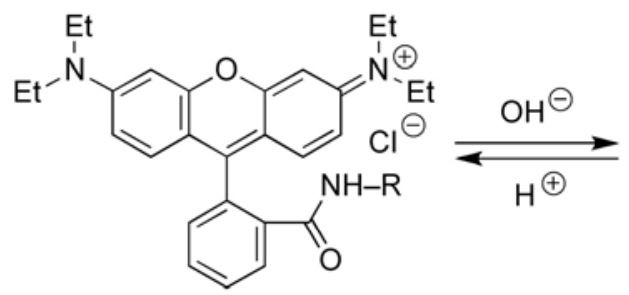

$1 \mathrm{~A}$

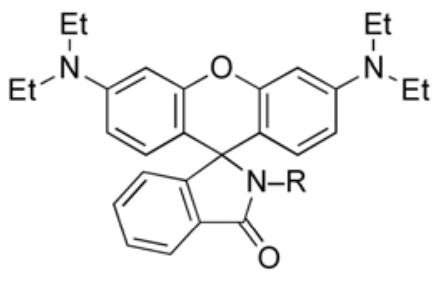

1B

Scheme 1. pH-Driven equilibrium between open and closed (spirolactam) forms of rhodamines. 
Frequently, grafting of a functionality as terminal groups of dendrimers enhances its properties. In the case of fluorescent groups, the presence of multiple fluorescent labels linked to dendrimers generally induces a brilliant fluorescence provided no quenching is caused by the close proximity of the fluorophores. ${ }^{3}$ We have shown that phosphorus-containing dendrimers are suitable for such purpose, ${ }^{4}$ also for obtaining brilliant two-photon absorption organic "nanodots", as efficient as inorganic quantum dots. ${ }^{5}$ Grafting rhodamine derivatives as terminal groups of phosphorus-containing dendrimers may allow an enhancement of their sensing properties in biology (fluorescence in acidic conditions). Here we report the synthesis of new derivatives of Rhodamine B and their grafting as terminal groups of phosphorus-containing dendrimers.

\section{Results and Discussion}

The phosphorus-containing dendrimers we synthesized contain $\mathrm{P}(\mathrm{S}) \mathrm{Cl}_{2}$ or aldehyde groups as terminal groups. Since the $\mathrm{P}(\mathrm{S}) \mathrm{Cl}_{2}$ group readily reacts with phenols Rhodamine $\mathrm{B}$ should be first functionalized to provide a phenol group, and the carboxylic acid group could serve for this purpose. As a linker for grafting various functionalities on $\mathrm{P}(\mathrm{S}) \mathrm{Cl}_{2}$ groups we have used tyramine, ${ }^{6}$ which appears to be suitable here too. The reaction of the tyramine $\mathrm{NH}_{2}$ function with the carboxylic acid group of Rhodamine B was attempted by two different ways. First, we tried the direct coupling using a classical peptidic coupling strategy based on the activation with hydroxybenzotriazole (HOBt) and dicyclohexylcarbodiimide (DCC); however, this attempt failed to afford the expected product. Then, we tried an indirect method (two steps) derived from the protocol for grafting of Rhodamine B to glycine. ${ }^{7}$ The first step was the esterification of the carboxylic acid group in Rhodamine B 1 with $N$-hydroxysuccinimide (NHS) in the presence of DCC. The resulting ester 2 was characterized by ${ }^{13} \mathrm{C}$ NMR, displaying the CO signal at $\delta 160.74$, while Rhodamine B 1 displays the CO signal at $\delta$ 167.7. The reaction of ester 2 with tyramine in acetonitrile and borate buffer formed compound 3, which was isolated as a white powder upon column chromatography (Scheme 2).

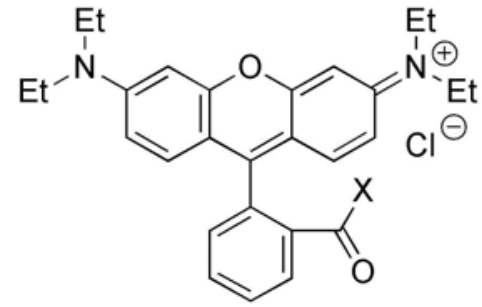

Scheme 2. Reagents and conditions: a. NHS, DCC, MeCN $45^{\circ} \mathrm{C}$, 1h, then r.t., $20 \mathrm{~h}$;

b. $\mathrm{MeCN} / \mathrm{H}_{3} \mathrm{BO}_{3}$ buffer $\mathrm{pH} 8.5(1: 1, \mathrm{v} / \mathrm{v})$, r.t., 36 h. 
Unexpectedly, compound $\mathbf{3}$ is colorless and non-fluorescent. Thus, the structure of $\mathbf{3}$ cannot be the open form 3A but the spirolactam form 3B; this was confirmed by the ${ }^{13} \mathrm{C}$ NMR signal at $\delta 65.13$ assigned to the spiro-carbon.

This result was unexpected but may be interesting for practical synthesis. THF and chloroform are good solvents for dendrimers and for spirolactam 3B. An open form is anticipated to be insoluble in such solvents and permanently fluorescent. Therefore, the synthesis of a phenol derivative of Rhodamine B was devised that is prevented from ring closure: 4-hydroxyphenylpiperazine was chosen for this purpose. The peptide coupling strategy used previously was successfully applied to afford compound $\mathbf{4}$, which is dark purple in color and fluorescent as anticipated (Scheme 3). The open form $4 \mathrm{~A}$ was confirmed by the absence of ${ }^{13} \mathrm{C}$ NMR signal at about $\delta 65$ (spiro carbon) and by the signal at $\delta 167.87(\mathrm{~N}-\mathrm{C}=\mathrm{O})$.

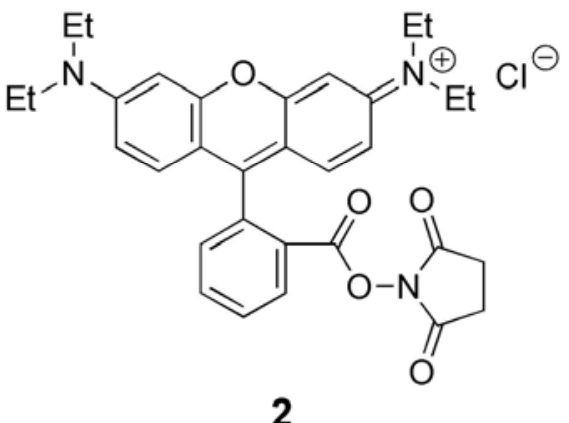

2

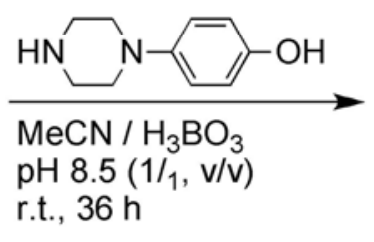

r.t., $36 \mathrm{~h}$

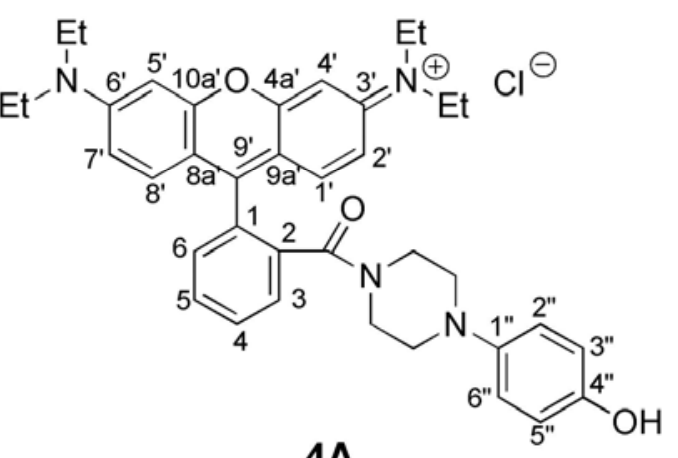

4A

\section{Scheme 3}

Using cesium carbonate as a base, Rhodamine derivatives $\mathbf{3 B}$ and $\mathbf{4 A}$ were grafted as terminal groups on the first generation dendrimer $\mathbf{5}-\mathbf{G}_{\mathbf{1}}{ }^{7}$ Monitoring the reaction of compound $3 \mathrm{~B}$ by ${ }^{31} \mathrm{P}$ NMR showed the disappearance of the $\mathrm{P}(\mathrm{S}) \mathrm{Cl}_{2}$ signal at $\delta 62.5$ and the appearance of a signal at $\delta 68.5$ corresponding to mono-substitution $[\mathrm{P}(\mathrm{S}) \mathrm{Cl}(\mathrm{OAr})]$; disappearance of the latter signal and the appearance of a new signal at $\delta 62.7$ indicated full substitution (dendrimer $\mathbf{5}-\mathbf{G}_{\mathbf{1}}$ ) (Scheme 4). ${ }^{31} \mathrm{P}$ NMR is a very sensitive tool for the characterization of phosphorus-containing dendrimers, ${ }^{8,9}$ mass spectrometry, including MALDI-Tof, is not useful for proving the purity of the phosphorhydrazone-containing dendrimers. ${ }^{10}$

Dendrimer $\mathbf{5}-\mathbf{G}_{\mathbf{1}}$ is not fluorescent, indicating that the closed rhodamine form is retained upon grafting to dendrimers. In an attempt to open the spiro-form (cf. Scheme 1), an equivalent amount $\left(1 \mathrm{H}^{+}\right.$per terminal group) of aqueous $\mathrm{HCl}(0.1 \mathrm{~N})$ was added to the solution of dendrimer 5-G $\mathbf{G}_{1}$ in THF; a pink color developed after $1.5 \mathrm{~h} .{ }^{31} \mathrm{P}$ and ${ }^{1} \mathrm{H}$ NMR showed that the overall structure of the dendrimer was not changed by the addition of $\mathrm{HCl}$. The ${ }^{13} \mathrm{C}$ NMR signal of the spiro carbon was still present indicating that most of the rhodamine moieties were not opened. Additional $\mathrm{HCl}$ did not open all spiro forms, the closed form prevailing in the equilibrium as confirmed by the very low fluorescence intensity of $\mathbf{5}-\mathbf{G}_{\mathbf{1}} \cdot \mathbf{H C l}$ compared to Rhodamine B (Figure 1) even in DMSO, which should favor the open form as polar solvents do in general. ${ }^{11}$ 


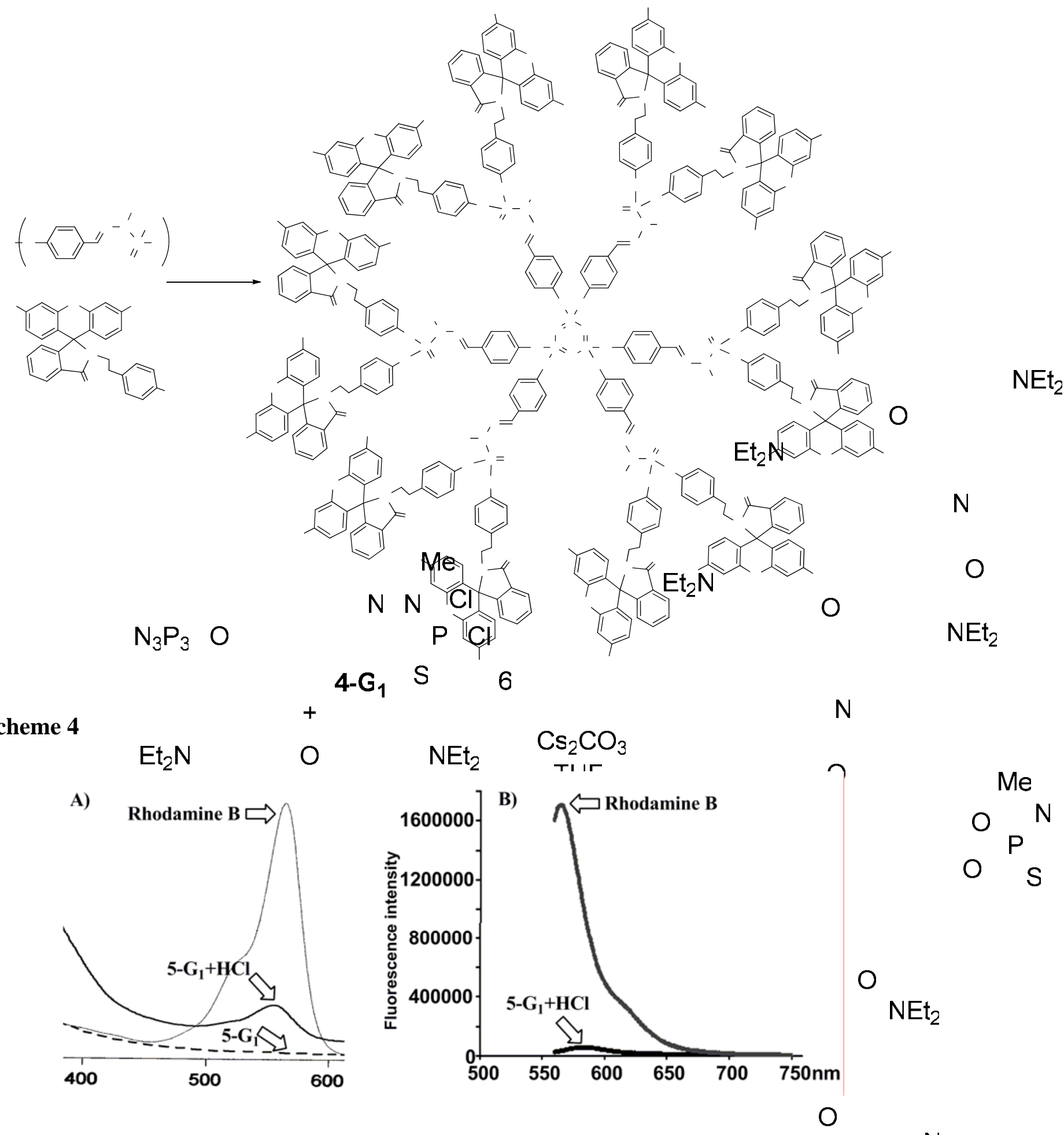

Figure 1. A) Vis spectra of Rhodamine $B$, dendrimer $\mathbf{5}-\mathbf{G}_{\mathbf{1}}$, and dendrimer $\mathbf{5}-\mathbf{G}_{\mathbf{1}} \cdot \mathbf{H C l}$ (enhanced $\mathbf{N}$ scale). B) Fluorescence spectra of Rhodamine B (ethanol) and dendrimer $\mathbf{5}-\mathbf{G}_{\mathbf{1}} \cdot \mathrm{HCl}$ (DMSO) after irradiation at $562 \mathrm{~nm}$. The spectra were normalized for the same Opticat $\mathrm{P}_{2} \mathrm{~N}$ sity at $562 \mathrm{~nm}$. 
Comparison of the ${ }^{1} \mathrm{H}$ and ${ }^{13} \mathrm{C}$ NMR spectra of $\mathbf{5}-\mathbf{G}_{\mathbf{1}}$ before and after addition of $\mathrm{HCl}$ reveals several differences (Figure 2; data from compounds 2, 3B, and $\mathbf{4 A}$ are also included). After addition of $\mathrm{HCl}$ some signals are displayed like in the open form (e.g., 4',5'-H), others like in the spiro form (e.g., 1-C and 3',6'-C), or in between both forms (e.g., 8a',9a'-C and 4',5'-C).

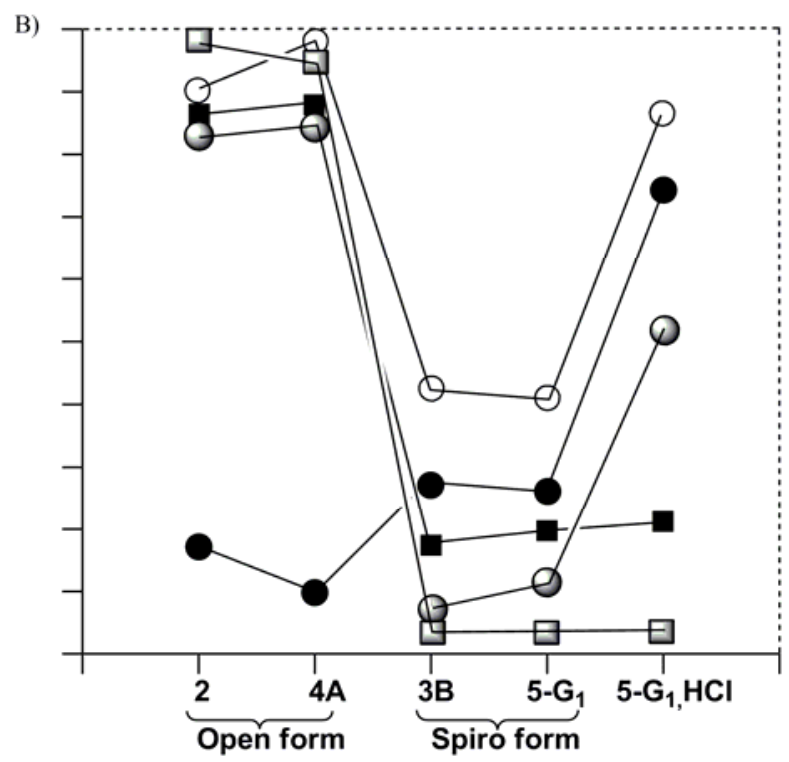

Figure 2. A) Numbering used for the NMR assignment of spirolactams. B) Chemical shifts of selected $\mathrm{H}$ and $\mathrm{C}$ atoms of xanthene moieties in $\mathbf{2}, \mathbf{4 a}, \mathbf{3 B}, \mathbf{5 G}_{\mathbf{1}}$, and $\mathbf{5 G}_{\mathbf{1}} \cdot \mathrm{HCl}: \circ: 4^{\prime}, 5^{\prime}-\mathrm{H}:{ }^{1} \mathrm{H}$ NMR, scale $\delta$ 6-7; •: 4',5'-C: ${ }^{13} \mathrm{C}$ NMR, scale $\delta$ 95-105; $\mathbf{~ : ~ 3 ' , 6 ' - C : ~}{ }^{13} \mathrm{C}$ NMR, scale $\delta 147-$ 157; •: 8a',9a'-C: ${ }^{13} \mathrm{C}$ NMR, scale $\delta$ 105-115; $\mathbf{\square}: 1-\mathrm{C}$ (=9'-C): ${ }^{13} \mathrm{C}$ NMR, scale $\left.\delta 60-160\right)$.

Addition of $\mathrm{HCl}$ affected the ${ }^{13} \mathrm{C}$ NMR chemical shifts of the xanthene ring, as well as the $\mathrm{NCH}_{2} \mathrm{CH}_{3}$ signal (5-G $\mathbf{G}_{\mathbf{1}}: \delta 44.04 ; \mathbf{5}-\mathbf{G}_{\mathbf{1}} \cdot \mathrm{HCl}: \delta$ 47.36). This is taken as evidence that the $\mathrm{NEt}_{2}$ groups were protonated, and that protonation opens only a few spirolactam rings, as indicated also by UV-Visible and fluorescence spectra (Figure 1). A gradient enhanced hydrogen-nitrogen multiple quantum coherence NMR experiment $\left({ }^{1} \mathrm{H}^{-15} \mathrm{~N}\right.$ HMBC) served to prove protonation at $\mathrm{NEt}_{2}$. In this experiment, dendrimer $\mathbf{5}-\mathbf{G}_{\mathbf{1}}$ afforded four ${ }^{15} \mathrm{~N}$ NMR signals as expected (Figure 3). By comparison with a previous experiment, ${ }^{12}$ the signals at $\delta-52$ and $\delta-249$ are attributed to the $\mathrm{CH}=\mathrm{N}$ and $\mathrm{N}-\mathrm{Me}$ groups of the dendrimer skeleton, respectively. ${ }^{1} \mathrm{H} /{ }^{15} \mathrm{~N}$ correlation allows to assign the signals at $\delta-226$ and $\delta-304$ to $\mathrm{N}-\mathrm{C}=\mathrm{O}$ and $\mathrm{NEt}_{2}$ groups of Rhodamine, respectively. $\mathbf{5}-\mathbf{G}_{\mathbf{1}} \cdot \mathbf{H C l}$ is less soluble than $\mathbf{5}-\mathbf{G}_{\mathbf{1}}$, and the same type of experiment required a longer time (48 h). A single new signal was observed at $\delta-328$, compatible with $\mathrm{Et}_{2} \mathrm{NH}^{+}$. However, this signal is less intense than the signal at $\delta-304$ (neutral $\mathrm{NEt}_{2}$ ) (Figure 3), and the ${ }^{1} \mathrm{H} \mathrm{NMR}$ spectrum recorded after the experiment displays a more intensive signal at $\delta 1.1$ for $\mathrm{CH}_{3}$ of the $\mathrm{NEt}_{2}$ groups beside the signal at $\delta 1.3\left(\mathrm{CH}_{3}\right.$ of $\left.\mathrm{Et}_{2} \mathrm{NH}^{+}\right)$, indicating that protonation is reversible. The ${ }^{1} \mathrm{H}-{ }^{15} \mathrm{~N}$ HMBC experiments confirm that protonation occurs mainly at the $\mathrm{NEt}_{2}$ groups. 

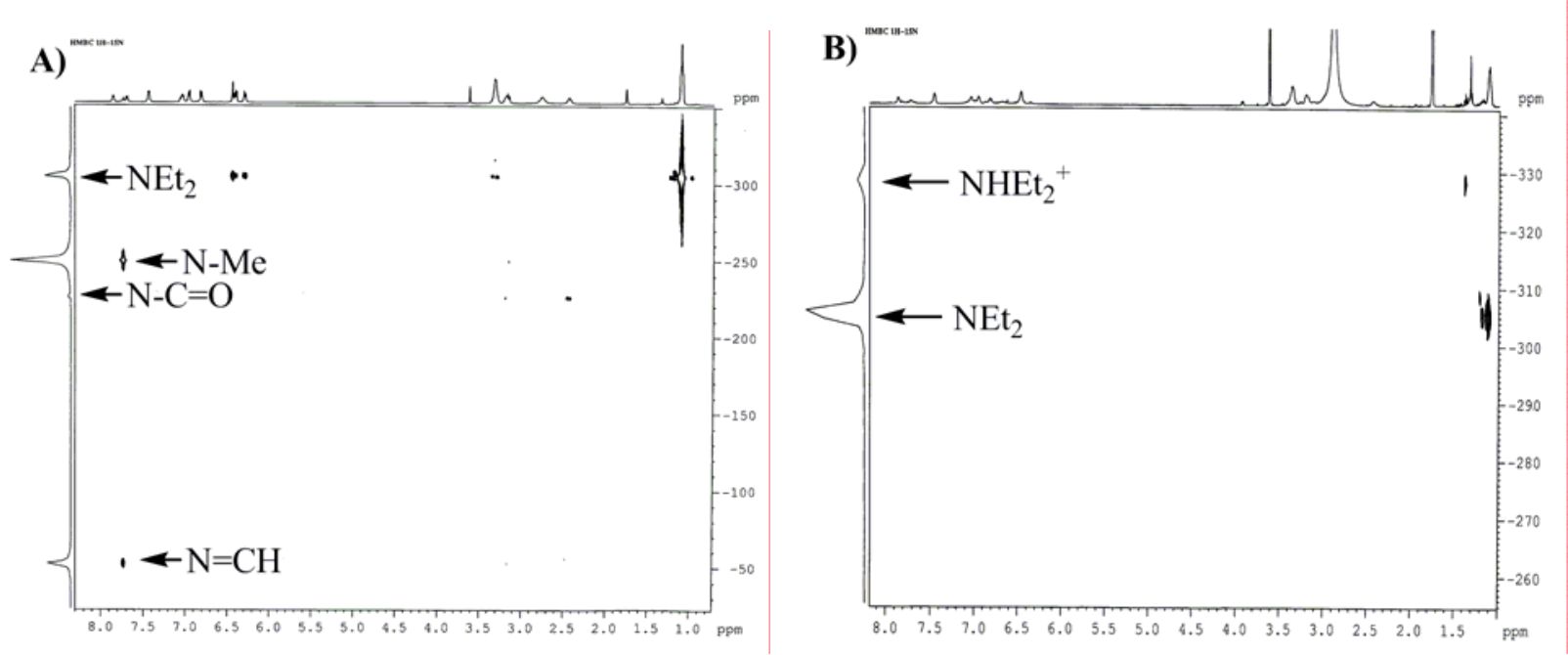

Figure 3. ${ }^{1} \mathrm{H}^{15}{ }^{15} \mathrm{HBMC}$ experiments. A) $\mathbf{5}-\mathbf{G}_{\mathbf{1}}$. B) $\mathbf{5}-\mathbf{G}_{\mathbf{1}} \cdot \mathrm{HCl}$ (focus on the $\mathrm{NEt}_{2}$ signal).

Rhodamine derivative $\mathbf{4}$, which cannot cyclize, was reacted with dendrimer $\mathbf{5}-\mathbf{G}_{\mathbf{1}}$. The solubility of both compounds is different: dendrimer $\mathbf{5}-\mathbf{G}_{\mathbf{1}}$ was dissolved in THF and the rhodamine derivative $\mathbf{4}$ in acetonitrile. Upon mixing both reactant solutions the partly substituted dendrimer precipitates in the solvent mixture preventing the reaction to drive to completion.

\section{Conclusions}

We have synthesized two new rhodamine derivatives functionalized with a phenol, one for which the equilibrium is shifted toward the colorless and non-fluorescent spirolactam form $\mathbf{3 B}$ and one which can be only in the open colored and fluorescent form 4A. Due to problems of solubility, the salt 4 could not be grafted on a phosphorus-containing dendrimer, but the neutral rhodamine derivative 3B was successfully grafted as terminal groups. A few papers have reported the synthesis of dendrimers labeled with rhodamine (rhodamine being linked to one or a few terminal functions ${ }^{13,14}$ ) but to the best of our knowledge, $\mathbf{5}-\mathbf{G}_{\mathbf{1}}$ is the first example of a dendrimer bearing rhodamine moieties on all terminal groups. Addition of $\mathrm{HCl}$ did not damage the structure of the dendrimer, and does not open the spirolactam form of the rhodamine terminal groups (or only some of them). Protonation of the $\mathrm{NEt}_{2}$ substituent of rhodamine takes place; this shows that the spirolactam form of the rhodamine derivative $3 \mathbf{B}$ is particularly stable.

\section{Experimental Section}

General. All manipulations were carried out with standard high vacuum and dry-argon techniques. Filtrations were also carried out under argon. The solvents were dried (THF and 
diethyl ether over sodium/benzophenone, pentane and dichloromethane over phosphorus pentoxide, acetonitrile over calcium hydride) and distilled prior to use. ${ }^{1} \mathrm{H},{ }^{13} \mathrm{C}$, and ${ }^{31} \mathrm{P}$ NMR spectra were recorded with Bruker AC 200, AC 250, DPX 300 or AMX 400 spectrometers. References for NMR chemical shifts are $85 \% \mathrm{H}_{3} \mathrm{PO}_{4}$ in water for ${ }^{31} \mathrm{P}, \mathrm{SiMe}_{4}$ for ${ }^{1} \mathrm{H}$ and ${ }^{13} \mathrm{C}$, and $\mathrm{CH}_{3} \mathrm{NO}_{2}$ for ${ }^{15} \mathrm{~N}$ NMR. ${ }^{13} \mathrm{C}$ NMR signals were assigned using $J_{\text {mod }}$, two dimensional $\mathrm{HMBC}$, and HMQC, broad band or $\mathrm{CW}{ }^{31} \mathrm{P}$ decoupling experiments when necessary, and were found consistent with previously reported data for the rhodamine derivatives. ${ }^{15}$ The numbering used for NMR assignments for open forms 2, 4A and for spirolactam forms (3B, dendrimers $\mathbf{5}-\mathbf{G}_{\mathbf{1}}$ and $\mathbf{5}$ $\mathbf{G}_{\mathbf{1}} \cdot \mathrm{HCl}$ ) is shown in Scheme 3 and Figure 2, respectively. Yields are not optimized.

\section{$\mathrm{N}$-[6-(Diethylamino)-9-[2-[(2,5-dioxopyrrolidin-1-yloxy)carbonyl]phenyl]-3H-xanthen-3-yl-} idene]- $\mathrm{N}$-ethylethanaminium (2). Applying the method previously described, ${ }^{7}$ a solution of dicyclohexylcarbodiimide $(1.2 \mathrm{~g}, 5.8 \mathrm{mmol})$ in acetonitrile $(50 \mathrm{~mL})$ was added dropwise to a solution of Rhodamine B (1; $2.4 \mathrm{~g}, 5 \mathrm{mmol})$ and $N$-hydroxysuccinimide $(0.6 \mathrm{~g}, 5.2 \mathrm{mmol})$ in acetonitrile $(100 \mathrm{~mL})$ at $45^{\circ} \mathrm{C}$. The resulting mixture was stirred at $45{ }^{\circ} \mathrm{C}$ for $1 \mathrm{~h}$, then at room temperature for $20 \mathrm{~h}$. After filtration and evaporation to dryness, the crude product was purified by crystallization from absolute ethanol, to afford 2 as a dark purple powder $(1.04 \mathrm{~g}, 29 \%) .{ }^{1} \mathrm{H}$ NMR $\left(\mathrm{CDCl}_{3}, 300 \mathrm{MHz}\right): \delta 1.35\left(\mathrm{t},{ }^{3} \mathrm{~J}=6.6 \mathrm{~Hz}, 12 \mathrm{H}, \mathrm{CH}_{3}\right), 2.79\left(\mathrm{~s}, 4 \mathrm{H}, \mathrm{CH}_{2} \mathrm{CH}_{2}\right), 3.66\left(\mathrm{q},{ }^{3} \mathrm{~J}=\right.$ $\left.6.6 \mathrm{~Hz}, 8 \mathrm{H}, \mathrm{NCH}_{2}\right), 6.9$ (br s, 4H, 2', 4', 5', 7'-H), 7.10 (d, $\left.{ }^{3} J=9.6 \mathrm{~Hz}, 2 \mathrm{H}, 1^{\prime}, 8^{\prime}-\mathrm{H}\right), 7.50$ (d, ${ }^{3} J=$ $7.2 \mathrm{~Hz}, 1 \mathrm{H}, 6-\mathrm{H}), 7.84\left(\mathrm{dd},{ }^{3} J=7.5 \mathrm{~Hz}, 1 \mathrm{H}, 4-\mathrm{H}\right), 8.00\left(\mathrm{dd},{ }^{3} J=7.2 \mathrm{~Hz}, 1 \mathrm{H}, 5-\mathrm{H}\right), 8.44\left(\mathrm{~d},{ }^{3} J=\right.$ $7.8 \mathrm{~Hz}, 1 \mathrm{H}, 3-\mathrm{H}) .{ }^{13} \mathrm{C}\left\{{ }^{1} \mathrm{H}\right\} \mathrm{NMR}\left(\mathrm{CDCl}_{3}, 75.5 \mathrm{MHz}\right): \delta 12.73\left(\mathrm{CH}_{3}\right), 25.62\left(\mathrm{CH}_{2} \mathrm{CH}_{2}\right), 46.29$ $\left(\mathrm{NCH}_{2}\right), 96.77$ (4',5'-C), 113.46 (8a',9a'-C), 114.47 (2',7'-C), 130.68 (2,6-C), 130.95 (1', 8' -C), 131.13 (4-C), 131.79 (5-C), 134.54 (1-C), 134.94 (3-C), 155.66 (3',6'-C), 157.83 (9',4a',10a'C), $160.74\left(\mathrm{CO}_{2}\right), 168.64(\mathrm{NC}=\mathrm{O})$.

3',6'-Bis(diethylamino)-2-(4-hydroxyphenethyl)spiro[isoindoline-1,9'-xanthen]-3-one (3B). A solution of tyramine $(210 \mathrm{mg}, 1.5 \mathrm{mmol})$ in borate buffer at $\mathrm{pH} 8.5(40 \mathrm{~mL})$ was added to a solution of $2(800 \mathrm{mg}, 1.4 \mathrm{mmol})$ in acetonitrile $(40 \mathrm{~mL})$. The resulting mixture was stirred for $36 \mathrm{~h}$ at room temperature. Evaporation of acetonitrile induced precipitation in the borate buffer. The precipitate was filtered off and crystallized from ethanol containing water $(1 \% \mathrm{v})$. The product was further purified by column chromatography (silica; dichloromethane $\rightarrow$ dichloromethane/ethanol 9/1, v/v) and isolated as a white powder 3B $(157 \mathrm{mg}, 20 \%) .{ }^{1} \mathrm{H} \mathrm{NMR}\left(\mathrm{CDCl}_{3}\right.$, $300 \mathrm{MHz}): \delta 1.18\left(\mathrm{t},{ }^{3} \mathrm{~J}=7.2 \mathrm{~Hz}, 12 \mathrm{H}, \mathrm{CH}_{3}\right), 2.39\left(\mathrm{t},{ }^{3} \mathrm{~J}=8.4 \mathrm{~Hz}, 2 \mathrm{H}, \mathrm{CH}_{2} \mathrm{Ar}\right), 3.28\left(\mathrm{t},{ }^{3} J=8.4\right.$ $\left.\mathrm{Hz}, 2 \mathrm{H}, \mathrm{CH}_{2} \mathrm{~N}\right), 3.35\left(\mathrm{q},{ }^{3} \mathrm{~J}=7.2 \mathrm{~Hz}, 8 \mathrm{H}, \mathrm{CH}_{2} \mathrm{~N}\right), 5.85(\mathrm{~s}, 1 \mathrm{H}, \mathrm{OH}), 6.27\left(\mathrm{~d},{ }^{3} \mathrm{~J}=9.0 \mathrm{~Hz}, 2 \mathrm{H}\right.$, 2',7'-H), 6.43 (s, 2H, 4',5'-H), 6.44 (d, ${ }^{3} \mathrm{~J}=11.0 \mathrm{~Hz}, 2 \mathrm{H}, 1$ ', 8'-H), 6.73, 6.70 (AA', 2H, 3', 5'H), 6.86, 6.83 (BB', 2H, 2",6”-H), 7.14 (m, 1H, 7-H), 7.46 (m, 2H, 5,6-H), 7.94 (m, 1H, 4-H).

${ }^{13} \mathrm{C}\left\{{ }^{1} \mathrm{H}\right\}$ NMR $\left(\mathrm{CDCl}_{3}, 75.5 \mathrm{MHz}\right): \delta 12.59\left(\mathrm{CH}_{3}\right), 33.73\left(\mathrm{ArCH}_{2}\right), 42.37\left(\mathrm{CH}_{2} \mathrm{~N}\right), 44.37\left(\mathrm{CH}_{2}\right.$, 65.13 (1-C), 97.72 (4',5'-C), 105.71 (8a'9a'-C), 108.14 (2',7'-C), 115.15 (3',5'-C), 122.78 (4C), 123.80 (7-C), 128.07 (5-C), 129.00 (1',8'-C), 129.81 (2",6”-C), 131.31 (3a-C), 131.63 (1"'C), 132.32 (6-C), 148.81 (3',6'-C), 153.29 (7a-C), 153.47 (4a',10a'-C), 154.27 (4”'-C), 167.80 
(3-C). MS-ESI: $m / z$ 562.7 $[\mathrm{M}+\mathrm{H}]^{+}, 584.7[\mathrm{M}+\mathrm{Na}]^{+}$. Anal. calcd. for $\mathrm{C}_{36} \mathrm{H}_{39} \mathrm{~N}_{3} \mathrm{O}_{3}$ (561.71): C, 76.98; H, 7.00; N, 7.48. Found: C, 76.79; H, 7.23; N, 7.47.

$\mathrm{N}$-[6-(Diethylamino)-9-[2-[4-(4-hydroxyphenyl)piperazine-1-carbonyl]phenyl]-3H-xanthen3-ylidene]- $\boldsymbol{N}$-ethylethanaminium chloride (4A). A solution of compound $\mathbf{1}$ (100 mg, $0.17 \mathrm{mmol})$ in acetonitrile $(5 \mathrm{~mL})$ was added to a suspension of 4-hydroxyphenylpiperazine (30.3 $\mathrm{mg}, 0.17 \mathrm{mmol}$ ) in borate buffer at $\mathrm{pH} 8.5(5 \mathrm{~mL})$. The resulting mixture (suspension) was stirred for $12 \mathrm{~h}$ at room temperature. After evaporation of solvents, chloroform $(10 \mathrm{~mL})$ was added to the crude mixture and filtered. The solution was evaporated to dryness, and the crude product was purified by crystallization (twice) in absolute ethanol. Compound 4A was isolated as a dark purple powder (12 mg, 11\%). ${ }^{1} \mathrm{H}$ NMR $\left(\mathrm{CD}_{3} \mathrm{OD}, 300 \mathrm{MHz}\right): \delta 1.29\left(\mathrm{t},{ }^{3} \mathrm{~J}_{\mathrm{HH}}=7.2 \mathrm{~Hz}\right.$, $\left.12 \mathrm{H}, \quad \mathrm{N}-\mathrm{CH}_{2} \mathrm{CH}_{3}\right), \quad 2.45-2.80\left(\mathrm{~m}, 4 \mathrm{H}, \mathrm{C}_{6} \mathrm{H}_{4} \mathrm{NCH}_{2} \mathrm{CH}_{2}\right), 3.54\left(\mathrm{t},{ }^{3} J_{\mathrm{HH}}=4.5 \mathrm{~Hz}, 4 \mathrm{H}\right.$, $\mathrm{C}_{6} \mathrm{H}_{4} \mathrm{NCH}_{2} \mathrm{CH}_{2}$ ), 3.68 (q, ${ }^{3} J_{\mathrm{HH}}=7.2 \mathrm{~Hz}, 8 \mathrm{H}, \mathrm{NCH}_{2} \mathrm{CH}_{3}$ ), 6.69, 6.66 (AA', 2H, 3",5"-H), 6.75, $6.72\left(\mathrm{BB}\right.$ ', 2H, 2", 6”-H), $6.98\left(\mathrm{~d},{ }^{4} J_{\mathrm{HH}}=2 \mathrm{~Hz}, 2 \mathrm{H}, 4{ }^{\prime}, 5{ }^{\prime}-\mathrm{H}\right), 7.08\left(\mathrm{dd},{ }^{3} J_{\mathrm{HH}}=9.6 \mathrm{~Hz},{ }^{4} J_{\mathrm{HH}}=2\right.$ $\left.\mathrm{Hz}, 2 \mathrm{H}, 2^{\prime}, 7^{\prime}-\mathrm{H}\right), 7.33\left(\mathrm{~d},{ }^{3} J_{\mathrm{HH}}=9.6 \mathrm{~Hz}, 2 \mathrm{H}, 1^{\prime}, 8^{\prime}-\mathrm{H}\right), 7.57\left(\mathrm{dd},{ }^{3} J_{\mathrm{HH}}=8 \mathrm{~Hz},{ }^{4} J_{\mathrm{HH}}=1 \mathrm{~Hz}, 1 \mathrm{H}, 6-\right.$ $\mathrm{H}), 7.72\left(\mathrm{dt},{ }^{3} J_{\mathrm{HH}}=8 \mathrm{~Hz},{ }^{4} J_{\mathrm{HH}}=1 \mathrm{~Hz}, 1 \mathrm{H}, 4-\mathrm{H}\right), 7.79(\mathrm{~m}, 2 \mathrm{H}, 3,5-\mathrm{H}) .{ }^{13} \mathrm{C}\left\{{ }^{1} \mathrm{H}\right\} \mathrm{NMR}\left(\mathrm{CD}_{3} \mathrm{OD}\right.$, $75.5 \mathrm{MHz}): \delta 11.43\left(\mathrm{NCH}_{2} \mathrm{CH}_{3}\right), 41.68,45.25\left(2 \mathrm{~s}, \mathrm{C}_{6} \mathrm{H}_{4} \mathrm{NCH}_{2} \mathrm{CH}_{2}\right), 45.49\left(\mathrm{NCH}_{2} \mathrm{CH}_{3}\right), 50.97$, 51.40 (2s, $\left.\mathrm{C}_{6} \mathrm{H}_{4} \mathrm{NCH}_{2} \mathrm{CH}_{2}\right), 95.93$ (4',5'-C), 113.49 (8a', 9a'-C), 114.04 (2',7'-C), 115.25 (3', 5'C), 119.10 (2”,6”-C), 127.54 (6-C), 129.93 (4-C), 130.17 (5-C), 130.64 (2-C), 131.99 (1',8'-C), 135.40 (1-C), 135.46 (3-C), 144.10 (4”-C), 152.12 (1”-C), 155.62 (9'-C), 155.80 (3',6'-C), 157.88 (4a',10a'-C), $167.87(\mathrm{NC}=\mathrm{O})$. Anal. calcd. for $\mathrm{C}_{38} \mathrm{H}_{43} \mathrm{ClN}_{4} \mathrm{O}_{3}(639.23)$ : C, 71.40; $\mathrm{H}, 6.78$; N, 8.77. Found: C, 71.29; H, 6.65; N, 8.67.

Dendrimer $\mathbf{5}-\mathbf{G}_{\mathbf{1}}$. Cesium carbonate $(114 \mathrm{mg}, 0.351 \mathrm{mmol})$ was added to a solution of 3B (100 mg, $0.18 \mathrm{mmol})$ and first generation dendrimer $\mathbf{4}_{-\mathbf{G}_{\mathbf{1}}}{ }^{8 \mathrm{~b}}(26.6 \mathrm{mg}, 14.5 \mu \mathrm{mol})$ in THF $(5 \mathrm{~mL})$. The resulting mixture was stirred at $50{ }^{\circ} \mathrm{C}$ for $12 \mathrm{~h}$. After filtration, the filtrate was evaporated to dryness. The crude product was dissolved in a minimum of dichloromethane. Upon pouring into an ice-cold mixture of pentane/diethylether $(4 / 1,300 \mathrm{~mL})$ a precipitate was formed. This process was repeated twice to afford dendrimer $\mathbf{5}-\mathbf{G}_{\mathbf{1}}$ as a white powder $(107 \mathbf{m g}$, 91\%). ${ }^{31} \mathrm{P}\left\{{ }^{1} \mathrm{H}\right\}$ NMR (THF-d $\left.8,121.5 \mathrm{MHz}\right): \delta=8.53\left(\mathrm{~s}, \mathrm{~N}_{3} \mathrm{P}_{3}\right), 62.69$ (s, P=S). ${ }^{1} \mathrm{H}$ NMR (THF$d_{8}, 300 \mathrm{MHz}$ ): $\delta=1.11\left(\mathrm{~m}, 144 \mathrm{H}, \mathrm{NCH}_{2} \mathrm{CH}_{3}\right), 2.43$ (br s, $24 \mathrm{H}, \mathrm{C}_{6} \mathrm{H}_{4} \mathrm{CH}_{2} \mathrm{CH}_{2} \mathrm{~N}$ ), 3.18 (br s, 42H, $\left.\mathrm{C}_{6} \mathrm{H}_{4} \mathrm{CH}_{2} \mathrm{CH}_{2} \mathrm{~N}, \mathrm{NCH}_{3}\right), 3.32\left(\mathrm{~m}, 96 \mathrm{H}, \mathrm{NCH}_{2} \mathrm{CH}_{3}\right), 6.28\left(\mathrm{~m}, 24 \mathrm{H}, 2^{\prime}, 7^{\prime}-\mathrm{H}\right), 6.33-6.50(\mathrm{~m}, 48 \mathrm{H}$, 1',4',5',8'-H), 6.80 (m, 24H, 3",5”-H), 6.95 (m, 24H, 2",6”-H), 7.04 (m, 24H, 7-H, c-H), 7.41 (m, 24H, 5,6-H), 7.60-7.75 (m, 18H, b-H, CH=N), 7.81 (br s, 12H, 4-H). ${ }^{13} \mathrm{C}\left\{{ }^{1} \mathrm{H}\right\}$ NMR (THFd8, $75.5 \mathrm{MHz}): \delta=12.01\left(\mathrm{~s}, \mathrm{NCH}_{2} \mathrm{CH}_{3}\right), 32.80$ (br s, $\left.\mathrm{NCH}_{3}\right), 33.92\left(\mathrm{C}_{6} \mathrm{H}_{4} \mathrm{CH}_{2} \mathrm{CH}_{2} \mathrm{~N}\right), 41.84$ $\left(\mathrm{C}_{6} \mathrm{H}_{4} \mathrm{CH}_{2} \mathrm{CH}_{2} \mathrm{~N}\right), 44.04\left(\mathrm{NCH}_{2} \mathrm{CH}_{3}\right), 64.34$ (1-C), 97.59 (4',5'-C), 106.16 (8a',9a'-C), 107.96 (2',7'-C), 121.02 (2s, 3",5”,c-C), 122.20 (4-C), 123.64 (7-C), 127.63 (5-C), 128.67 (2”,6”,b-C), 129.34 (1',8'-C), 131.68 (1', a-C), 131.88 (3a,6-C), $136.56(\mathrm{CH}=\mathrm{N}), 148.64$ (d-C), 148.99 (3',6'C), 153.45 (7a,4a',10a',4"-C), 166.50 (3-C). Anal. Calcd. for $\mathrm{C}_{480} \mathrm{H}_{504} \mathrm{~N}_{51} \mathrm{O}_{42} \mathrm{P}_{9} \mathrm{~S}_{6}$ (8130.61): C, 70.91; H, 6.25; N, 8.79. Found: C, 71.09; H, 6.36; N, 8.66.

Dendrimer $\mathbf{5}-\mathbf{G}_{\mathbf{1}} \cdot \mathbf{H C l}$. To a solution of dendrimer $\mathbf{5}-\mathbf{G}_{\mathbf{1}}(37 \mathrm{mg}, 51.3 \mu \mathrm{mol})$ in THF-d $(2 \mathrm{~mL})$, was added $0.1 \mathrm{~N} \mathrm{HCl}(713 \mu \mathrm{l})$. The mixture was stirred at room temperature for $36 \mathrm{~h}$, and 
analyzed by NMR. ${ }^{31} \mathrm{P}\left\{{ }^{1} \mathrm{H}\right\}$ NMR (THF-d, $\left.121.5 \mathrm{MHz}\right): \delta 8.56\left(\mathrm{~s}, \mathrm{~N}_{3} \mathrm{P}_{3}\right), 62.64(\mathrm{~s}, \mathrm{P}=\mathrm{S}) .{ }^{1} \mathrm{H}$ NMR (THF-d $\left.d_{8}, 300 \mathrm{MHz}\right): \delta=1.33\left(\mathrm{~m}, 144 \mathrm{H}, \mathrm{NCH}_{2} \mathrm{CH}_{3}\right), 2.38$ (br s, $24 \mathrm{H}, \mathrm{C}_{6} \mathrm{H}_{4} \mathrm{CH}_{2} \mathrm{CH}_{2} \mathrm{~N}$ ), 3.11 (br s, 42H, $\left.\mathrm{C}_{6} \mathrm{H}_{4} \mathrm{CH}_{2} \mathrm{CH}_{2} \mathrm{~N}, \mathrm{NCH}_{3}\right), 3.38$ (m, 96H, $\left.\mathrm{NCH}_{2} \mathrm{CH}_{3}\right), 6.48$ (m, 24H, 2', 7'-H), 6.61 (m, 24H, 1',8'-H), 6.73 (m, 24H, 3",5'-H), 6.84 (m, 48H, 2", 6”-H, 4',5'-H), 6.92 (m, 24H, 7,c$\mathrm{H}), 7.50(\mathrm{~m}, 24 \mathrm{H}, 5,6-\mathrm{H}), 7.62(\mathrm{~m}, 12 \mathrm{H}, \mathrm{b}-\mathrm{H}), 7.75$ (br s, 6H, CH=N), 7.80 (m, 12H, 4-H). ${ }^{13} \mathrm{C}\left\{{ }^{1} \mathrm{H}\right\} \quad \mathrm{NMR} \quad\left(\mathrm{THF}-d_{8}, 75.5 \mathrm{MHz}\right): \delta 11.21 \quad\left(\mathrm{NCH}_{2} \mathrm{CH}_{3}\right), 32.46 \quad\left(\mathrm{br}, \mathrm{NCH}_{3}\right), 33.66$ $\left(\mathrm{C}_{6} \mathrm{H}_{4} \mathrm{CH}_{2} \mathrm{CH}_{2} \mathrm{~N}\right), 42.06\left(\mathrm{C}_{6} \mathrm{H}_{4} \mathrm{CH}_{2} \mathrm{CH}_{2} \mathrm{~N}\right), 47.36\left(\mathrm{~N}-\mathrm{CH}_{2}-\mathrm{CH}_{3}\right), 64.59$ (1-C), 102.63 (4',5'-C), 110.40 (8a',9a'-C), 111.64 (2',7'-C), 120.97 (br, 3”,5”,c-C), 122.89 (4-C), 123.42 (7-C), 128.61 (5-C), 129.21 (2”,6”,b-C), 129.42 (1',8'-C), 130.71 (1",a-C), $132.96(3 a, 6-C), 136.06(\mathrm{CH}=\mathrm{N})$, 145.46 (3',6'-C), 149.01 (d-C), 152.87 (7a,4a',10a',4”-C), 167.85 (3-C).

\section{Acknowledgements}

Y.W. thanks ITAV (Institut des Technologies Avancées du Vivant) and the CNRS for a PhD grant, and the ANR PCV (BIODENDRIDOT) for financial support.

\section{References}

1. Kim, H. N.; Lee, M. H.; Kim, H. J.; Kim, J. S.; Yoon, J. Chem. Soc. Rev. 2008, 37, 1465.

2. (a) Adamczyk, M.; Grote, J. Bioorg. Med. Chem. Lett. 2003, 13, 2327. (b) Huang, J.; Xu, Y.; Qian, X. J. Org. Chem. 2009, 74, 2167.

3. Some recent reviews about fluorescent dendrimers: (a) Adronov, A.; Fréchet, J. M. J. Chem. Commun. 2000, 1701. (b) Burn, P. L.; Lo, S. C.; Samuel, I. D. W. Adv. Mater. 2007, 19, 1675. (c) Caminade, A. M.; Hameau, A.; Majoral, J. P. Chem. Eur. J. 2009, 15, 9270.

4. (a) Brauge, L.; Caminade, A. M.; Majoral, J. P.; Slomkowski, S.; Wolszczak, M. Macromolecules 2001, 34, 5599. (b) Leclaire, J.; Dagiral, R.; Fery-Forgues, S.; Coppel, Y.; Donnadieu, B.; Caminade, A. M.; Majoral, J. P. J. Am. Chem. Soc. 2005, 127, 15762. (c) Brauge, L.; Vériot, G.; Franc, G.; Deloncle, R.; Caminade, A. M.; Majoral, J. P. Tetrahedron 2006, 62, 11891. (d) Franc, G.; Mazères, S.; Turrin, C. O.; Vendier, L.; Duhayon, C.; Caminade, A. M.; Majoral, J. P. J. Org. Chem. 2007, 72, 8707. (e) Martinez-Ferrero, E.; Franc, G.; Mazères, S.; Turrin, C. O.; Caminade, A. M.; Majoral, J. P.; Sanchez, C. Chem. Eur. J. 2008, 14, 7658. (f) Fuchs, S.; Pla-Quintana, A.; Mazères, S.; Caminade, A. M.; Majoral, J. P. Org. Lett. 2008, 10, 4751.

5. (a) Mongin, O.; Krishna, T. R.; Werts, M. H. V.; Caminade, A. M.; Majoral, J. P.; Blanchard-Desce, M. Chem. Commun. 2006, 915. (b) Krishna, T. R.; Parent, M.; Werts, M. H. V.; Moreaux, L.; Gmouh, S.; Charpak, S.; Caminade, A. M.; Majoral, J. P.; BlanchardDesce, M. Angew. Chem. Int. Ed. 2006, 45, 4645. (c) Mongin, O.; Pla-Quintana, A.; 
Terenziani, F.; Drouin, D.; Le Droumaguet, C.; Caminade, A. M.; Majoral, J. P.; BlanchardDesce, M. New J. Chem. 2007, 31, 1354.

6. (a) Griffe, L.; Poupot, M.; Marchand, P.; Maraval, A.; Turrin, C. O.; Rolland, O.; Métivier, P.; Bacquet, G.; Fournié, J. J.; Caminade, A. M.; Poupot, R.; Majoral, J. P. Angew. Chem. Int. Ed. 2007, 46, 2523. (b) Rolland, O.; Griffe, L.; Poupot, M.; Maraval, A.; Ouali, A.; Coppel, Y.; Fournié, J. J.; Bacquet, G.; Turrin, C. O.; Caminade, A. M.; Majoral, J. P.; Poupot, R. Chem. Eur. J. 2008, 14, 4836. (c) Servin, P.; Laurent, R.; Romerosa, A.; Peruzzini, M.; Majoral, J. P.; Caminade, A. M. Organometallics 2008, 27, 2066.

7. Meng, Q.; Yu, M.; Zhang, H.; Ren, J.; Huang, D. Dyes and Pigments 2007, 73, 254.

8. (a) Launay, N.; Caminade, A. M.; Lahana, R.; Majoral, J. P. Angew. Chem. Int. Ed. Engl. 1994, 33, 1589. (b) Launay, N.; Caminade, A. M.; Majoral, J. P. J. Organomet. Chem. 1997, 529, 51.

9. (a) Brauge, L.; Magro, G.; Caminade, A. M.; Majoral, J. P. J. Am. Chem. Soc. 2001, 123, 6698; correction: ibid. J. Am. Chem. Soc. 2001, 123, 8446. (b) Maraval, V.; Caminade, A. M.; Majoral, J. P.; Blais, J. C. Angew. Chem. Int. Ed. 2003, 42, 1822. (c) Caminade, A. M.; Laurent, R.; Majoral, J. P. Adv. Drug Deliv. Rev. 2005, 57, 2130.

10. Blais, J. C.; Turrin, C. O.; Caminade, A. M.; Majoral, J. P. Anal. Chem. 2000, 72, 5097.

11. Nedelcev, T.; Racko, D.; Krupa, I. Dyes and Pigments 2008, 76, 550.

12. Deloncle, R.; Coppel, Y.; Rebout, C.; Majoral, J. P.; Caminade, A. M. Mag. Res. Chem. 2008, 46, 493.

13. Chang, T.; Rozkiewicz, D. I.; Ravoo, B. J.; Meijer, E. W.; Reinhoudt, D. N. Nano Letters 2007, 7, 978.

14. Dhanikula, R. S.; Argaw, A.; Bouchard J. F.; Hildgen, P. Mol. Pharm. 2008, 5, 105.

15. Ramos, S. S.; Vilhena, A. F.; Santos, L.; Almeida, P. Magn. Res. Chem. 2000, 38, 475. 